\title{
ANALISIS ATAS PELAKSANAAN FUNGSI PENGAWASAN PENGELOLAAN KEUANGAN DAERAH OLEH ANGGOTA DEWAN PERWAKILAN RAKYAT DAERAH KABUPATEN PUNCAK JAYA
}

\author{
Oleh : \\ Iskandar Wonda \\ Herman Karamoy \\ Ventje Ilat
}

\begin{abstract}
The purpose of this study is to analyze the local financial management supervision by the local parliament members period 2009-2014 in Puncak Jaya regency and stuff underlying onset of these conditions. The data used in this research were the primary data using the instrument as a list of questions with in-depth interviews to the research informants. The subjects were legislators of Puncak Jaya Regency period of 2009-2014 totaling 24 people. The method used were qualitative descriptive analysis.

The results showed that the personal background would have less effect on the function of supervision of local financial management. The political background effect on the supervisory function of financial management at Puncak Jaya Regency legislators. The legislator knowledge about the budget effect to a good supervision of the local financial management. The legislator who have a good understanding of the local financial regulatory would easy to supervise whether the budget has been run according to predetermined objectives and to detect the occurrence of budget leaks.
\end{abstract}

Keywords: Personal Background, Political Background, Legislators Knowledge about the Budget, Supervisory Function of the Local Financial Management by the Local Legislators. 


\section{PENDAHULUAN}

\subsection{Latar Belakang}

Sejak dikeluarkannya peraturan tentang otonomi daerah yaitu Undang-undang (UU) Nomor 22 Tahun 1999 juncto UU Nomor 32 Tahun 2004 tentang Pemerintahan Daerah dan UU Nomor 25 Tahun 1999 juncto UU Nomor 33 Tahun 2004 tentang Perimbangan Keuangan antara Pemerintah Pusat dan Daerah, maka kekuasaan atau tanggung jawab yang dibebankan kepada Pemerintah Daerah untuk mengelola daerahnya secara maksimal menjadi lebih besar. Hal ini ditujukan agar distribusi dan pemanfaatan sumber daya alam nasional dapat merata dan menciptakan keseimbangan keuangan antara pemerintah daerah dan pemerintah pusat. Dalam konteks tersebut, manajemen keuangan daerah dikelola secara penuh oleh pemerintah daerah.

Kedua undang-undang tersebut telah mengubah akuntabilitas atau pertanggungjawaban pemerintah daerah dari pertanggungjawaban vertikal, yaitu kepada pemerintah pusat menjadi pertanggungjawaban horisontal yaitu kepada masyarakat melalui Dewan Perwakilan Rakyat Daerah (DPRD) (Halim dan Kusufi, 2012). Mengacu pada kedua undang-undang yang mengatur pengelolaan keuangan daerah, Pemerintah Pusat melalui Kementerian Dalam Negeri mengeluarkan dan memberlakukan petunjuk teknis pelaksanaannya, yakni Peraturan Menteri Dalam Negeri (Permendagri) Nomor 13 Tahun 2006 tentang Pedoman Pengelolaan Keuangan Daerah dan juga Permendagri yang mengatur tentang Pedoman Penyusunan APBD setiap tahunnya.

Berkaitan dengan itu, DPRD yang selanjutnya disebut Dewan harus lebih aktif dalam menangkap aspirasi yang berkembang di masyarakat dan kemudian mengadopsinya dalam berbagai bentuk kebijakan publik dan anggaran di daerah bersama-sama dengan pemerintah daerah.

Pada umumnya, lembaga legislatif mempunyai tiga fungsi yaitu: (1) fungsi legislasi (fungsi membuat peraturan perundang-undangan); (2) fungsi anggaran (fungsi menyusun anggaran); dan (3) fungsi pengawasan (fungsi untuk mengawasi kinerja eksekutif). Peraturan Pemerintah (PP) Nomor 58 Tahun 2005 tentang Pengelolaan Keuangan Daerah menjelaskan bahwa: (1) pengawasan atas keuangan daerah dilakukan oleh dewan, serta (2) adanya pemeriksaan terhadap pengelolaan keuangan daerah oleh lembaga eksternal yaitu Badan Pemeriksa Keuangan (BPK). Pengawasan terhadap pengelolaan keuangan daerah oleh lembaga legislatif (DPRD) terhadap lembaga eksekutif (Pemerintah Daerah) sangat penting dilakukan, karena pengawasan merupakan suatu usaha untuk menjamin adanya keserasian antara penyelenggaraan tugas pemerintah di daerah dan menjamin kelancaran penyelenggaraan pemerintah secara berdaya guna dan berhasil guna (Makeuda dikutip oleh Winarna dan Murni, 2007).

Untuk mendapatkan kinerja yang baik menuntut sumberdaya manusia yang berkualitas. Salah satu indikator sumberdaya manusia berkualitas adalah tingkat pendidikan. Tingkat pendidikan yang tinggi akan mampu membantu seseorang menyelesaikan tugasnya dengan baik. Kesesuaian latar belakang pendidikan juga berpengaruh dalam kinerja seseorang. Seseorang yang mempunyai latar belakang pendidikan yang sama dengan bidang pekerjaannya cenderung lebih mengerti tentang masalah atau pekerjaan yang sedang dihadapinya. Kualitas sumberdaya manusia juga ditentukan oleh masa kerja atau lamanya menjabat sebagai anggota DPRD bagi para anggota dewan. DPRD akan dapat memainkan perannya dengan baik apabila pimpinan dan anggota-anggotanya memiliki kualifikasi ideal, dalam arti memahami benar hak, tugas, wewenang dan fungsinya dan mampu mengaplikasikannya secara baik serta didukung dengan tingkat pendidikan dan pengalaman di bidang politik dan pemerintahan yang memadai (Yudono, 2002). Dengan masa kerja yang lebih lama bagi anggota legislatif tentunya telah lebih lama dan berpengalaman pula dalam menghadapi dan menyelesaikan masalah-masalah pemerintahan khususnya dalam menjalankan fungsi pengawasan.

Selanjutnya, Yudono (2002) juga menyatakan bahwa DPRD akan dapat memainkan peranannya dengan baik apabila pimpinan dan anggota-anggotanya berada dalam kualifikasi ideal, dalam arti memahami benar hak, tugas, dan wewenangnya dan mampu mengaplikasikannya secara baik, dan didukung dengan tingkat pendidikan dan pengalaman di bidang politik dan pemerintahan 
yang memadai. Akan tetapi kenyataannya, tingkat pendidikan para anggota DPRD masih rendah yang menyebabkan pengawasan atas pengelolaan keuangan daerah juga turut rendah. Selain itu, aparat daerah dengan latar belakang akuntansi dan/atau bergelar akuntan masih dapat dihitung dengan jari. Realitas ini mengakibatkan sebagian besar opini pemeriksaan dari Badan Pemeriksa Keuangan (BPKRI) selalu disclaimer opinion (tidak memberikan pendapat). Kejadian ini disebabkan oleh belum transparannya Pemerintah Daerah dalam mengungkapkan proses penyusunan dan pertanggungjawaban APBD kepada publik, salah satunya laporan keuangan diumumkan di media massa.

Fenomena tersebut mendorong penulis untuk melakukan penelitian dengan judul: "Analisis atas Pelaksanaan Fungsi Pengawasan Pengelolaan Keuangan Daerah oleh Anggota Dewan Perwakilan Rakyat Daerah Kabupaten Puncak Jaya”.

\subsection{Rumusan Masalah}

Berdasarkan latar belakang yang telah diuraikan sebelumnya, maka menarik untuk dikaji mengenai kondisi pengawasan pengelolaan keuangan daerah oleh anggota DPRD Kabupaten Puncak Jaya. Kajian ini mencakup juga hal-hal yang melatarbelakangi timbulnya kondisi tersebut.

\subsection{Tujuan Penelitian}

Tujuan penelitian ini adalah menganalisis kondisi pengawasan pengelolaan keuangan daerah oleh Anggota DPRD Kabupaten Puncak Jaya serta hal-hal yang melatarbelakangi timbulnya kondisi tersebut.

\subsection{Manfaat Penelitian}

Manfaat yang diharapkan dari penelitian ini adalah:

1. Manfaat kebijakan; hasil penelitian ini diharapkan dapat menjadi acuan bagi Pemerintah Daerah dalam implementasi fungsi pengawasan pengelolaan keuangan daerah, sehingga bermanfaat untuk mengevaluasi kinerja Tim Anggaran Pemerintah Daerah dari pihak legislatif. Selain itu, penelitian ini diharapkan dapat menjadi masukan bagi masyarakat dalam melakukan evaluasi terhadap kinerja Anggota DPRD Kabupaten Puncak Jaya dalam melaksanakan fungsi pengawasan pengelolaan keuangan daerah.

2. Manfaat empirik; hasil penelitian ini bisa dijadikan referensi dan kajian lebih lanjut dalam mengkaji faktor-faktor yang mempengaruhi fungsi pengawasan pengelolaan keuangan daerah pada Anggota DPRD kabupaten/kota lainnya. Penelitian ini diharapkan juga berkontribusi untuk pengembangan literatur Akuntansi Sektor Publik di Indonesia khususnya bidang kajian Sistem Pengendalian Internal Sektor Publik.

\section{LANDASAN TEORITIS}

\subsection{Akuntansi Sektor Publik}

Akuntansi sektor publik didefinisikan sebagai akuntansi dana masyarakat, yang berarti mekanisme teknik analisis dan analisis akuntansi yang diterapkan pada pengelolaan dana masyarakat di lembaga-lembaga tinggi negara dan departemen-departemen dibawahnya, pemerintah daerah, BUMN, BUMD, LSM dan yayasan sosial, maupun pada proyek-proyek kerja sama sektor publik dan swasta (Bastian, 2005).

\subsection{Keuangan Daerah}

Keuangan daerah adalah semua hak dan kewajiban daerah dalam rangka penyelenggaraan daerah yang dapat dinilai dengan finansial termasuk didalamnya segala bentuk kekayaan yang berhubungan dengan hak dan kewajiban daerah tersebut dan tentunya dalam batas-batas kewenangan daerah. Keuangan daerah dituangkan sepenuhnya ke APBD (Peraturan Pemerintah RI No. 58 Tahun 2005 tentang Pengelolaan Keuangan Daerah).

\subsection{Pengawasan Keuangan Daerah}

Pengawasan merupakan suatu rangkaian kegiatan pemantauan, pemeriksaan dan evaluasi terhadap pelaksanaan kebijakan politik. Pengawasan dilakukan untuk menjamin semua kebijakan 
program dan kegiatan yang dilakukan sesuai dengan aturan yang berlaku. Pengawasan Pemerintah Daerah adalah proses kegiatan yang ditujukan untuk menjamin agar pemerintah daerah berjalan sesuai dengan rencana dan ketentuan peraturan perundang-undangan yang berlaku (Keputusan Presiden Nomor 74 Tahun 2001 tentang Tata Cara Pengawasan Penyelenggaraan Pemerintahan Daerah). Pengawasan keuangan daerah yang dilakukan oleh DPRD yang berfokus kepada pengawasan terhadap pelaksanaan APBD.

\subsection{Fungsi DPRD sebagai Pengawas Keuangan Daerah}

Pasal 132 Peraturan Pemerintah Nomor 58 Tahun 2005 tentang Pengelolaan Keuangan Daerah menyatakan bahwa DPRD melakukan pengawasan terhadap pelaksanaan peraturan daerah tentang APBD. Hal ini sesuai juga dengan Peraturan Menteri Dalam Negeri Nomor 13 Tahun 2006 yang menyatakan bahwa untuk menjamin pencapaian sasaran yang telah ditetapkan, DPRD melakukan pengawasan atas pelaksanaan APBD. Hal ini berarti bahwa pengawasan yang dilakukan oleh DPRD merupakan pengawasan eksternal dan ditekankan pada pencapaian sasaran APBD.

Pengawasan merupakan tahap integral dengan keseluruhan tahap pada penyusunan dan pelaporan Anggaran dan Pendapatan Belanja Daerah (APBD). Menurut Alamsyah dalam Imelda Sari (2010), pengawasan terhadap APBD penting dilakukan untuk memastikan alokasi anggaran sesuai dengan prioritas pemerintah dan diajukan untuk kesejahteraan masyarakat, menjaga agar penggunaan APBD ekonomis, efisien dan efektif, serta menjaga agar pelaksanaan APBD benar-benar dapat dipertanggungjawaban atau dengan kata lain bahwa anggaran telah dikelola secara transparan dan akuntabel untuk meminimalkan terjadinya kebocoran.

\subsection{Kinerja DPRD dalam Pengawasan Keuangan Daerah}

Kinerja DPRD dalam melaksanakan peran dan fungsinya sebagai anggota dewan tergantung pada kompetensinya. Untuk dapat menjalankan kinerjanya dalam pengawasan keuangan daerah, anggota DPRD harus aktif mengikuti kegiatan-kegiatan pengawasan keuangan daerah (Imelda Sari, 2010). Kualitas yang diukur dengan pendidikan, pengetahuan, pengalaman, dan keahlian berpengaruh terhadap kinerja dewan pada saat melakukan fungsi pengawasan. Pendidikan dan pelatihan berkaitan dengan pengetahuan untuk masa yang akan datang.

\subsection{Latar Belakang Pribadi}

Latar belakang pribadi merupakan latar belakang diri dari yang melekat pada individu yang meliputi banyak aspek, antara lain: nama, jenis kelamin, usia, agama, latar belakang pendidikan, dan lain sebagainya. Latar belakang pribadi berkaitan erat dengan kualitas sumber daya manusia. Menurut Yuhertiana dalam Kombaitan (2009), kapasitas individu pada hakekatnya terbentuk dari proses pendidikan secara umum, baik melalui pendidikan formal, non-formal maupun informal.

\subsection{Latar Belakang Politik}

Latar belakang politik merupakan latar belakang dari pengalaman seseorang dalam berkecimpung di dunia politik. Partai politik dan parlemen (legislatif) merupakan dua aktor utama yang memperoleh mandat dari masyarakat sipil, berperan mengorganisir kekuasaan dan meraih kontrol atas negara untuk kepentingan masyarakat.

Dalam menjalankan tugasnya, anggota DPRD diharuskan mengikuti aturan kerja yang telah ditetapkan sesuai bidang masing-masing, di sinilah latar belakang politik terkadang menyebabkan perbedaan sudut pandang bahkan terjadinya perselisihan (La Palombara, 2002). Seorang anggota dewan harus mempunyai latar belakang politik yang baik dalam menjalankan tugasnya sebagai anggota dewan.

\subsection{Pengetahuan Dewan tentang Anggaran}

Pengetahuan dewan tentang anggaran dapat diartikan sebagai pengetahuan dewan terhadap mekanisme penyusunan anggaran mulai dari tahap perencanaan sampai pada tahap pertanggungjawaban serta pengetahuan dewan tentang peraturan perundangan yang mengatur pengelolaan keuangan daerah (APBD). Pengetahuan dewan tentang anggaran erat kaitannya dengan 
fungsi penganggaran dan fungsi pengawasan yang dimiliki oleh anggota dewan (Yudono, 2002). Anggota DPRD dituntut memiliki keterampilan dalam 'membaca' anggaran serta memiliki kemampuan terlibat dalam proses anggaran di daerah sehingga DPRD dapat bekerja secara efektif dalam melakukan pengawasan terhadap pelaksanaan anggaran.

\subsection{Konsep Dasar Anggaran Pendapatan dan Belanja Daerah (APBD)}

Menteri Negara Otonomi Daerah dan Pusat Antar Universitas-Studi Ekonomi UGM (2000) menyatakan bahwa APBD pada hakekatnya merupakan salah satu instrumen kebijakan yang dipakai sebagai alat untuk meningkatkan pelayanan umum dan kesejahteraan masyarakat di daerah. Peraturan Menteri Dalam Negeri Nomor 13 Tahun 2006 menyatakan bahwa Anggaran Pendapatan dan Belanja Daerah (APBD) disusun berdasarkan pendekatan kinerja, yaitu suatu sistem anggaran yang mengutamakan upaya pencapaian hasil kerja atau output dari perencanaan alokasi biaya atau input yang ditetapkan. APBD harus memuat sasaran yang diharapkan menurut fungsi belanja, standar pelayanan yang diharapkan dan perkiraan biaya satuan komponen kegiatan yang bersangkutan, serta bagian pendapatan APBD yang digunakan untuk membiayai belanja administrasi umum, belanja operasi dan pemeliharaan dan belanja modal/investasi (PP Nomor 105 Tahun 2000 tentang Pengelolaan dan Pertanggungjawaban Keuangan Daerah).

\section{KERANGKA KONSEPTUAL}

\subsection{Kerangka Konseptual Penelitian}

Kinerja pengelolaan keuangan daerah yang baik tergantung pada efektivitas fungsi pengawasan yang dilakukan oleh Dewan Perwakilan Rakyat Daerah (DPRD). Untuk menjalankan fungsi pengawasan tersebut, maka perlu ditunjang oleh tiga aspek penting, yaitu latar belakang pendidikan, latar belakang politik, dan pengetahuan anggota dewan tentang anggaran.

Menurut Truman (1960) dikutip oleh Werimon (2007), pengalaman dan pengetahuan yang tinggi akan sangat membantu seseorang dalam memecahkan persoalan yang dihadapinya sesuai dengan kedudukan anggota DPRD sebagai wakil rakyat. Dengan mengetahui tentang anggaran diharapkan anggota Dewan dapat mendeteksi adanya pemborosan dan kebocoran anggaran. Sehingga dapat dirumuskan dalam kerangka konseptual berikut ini.

\section{Gambar 3.1 Kerangka Konseptual}

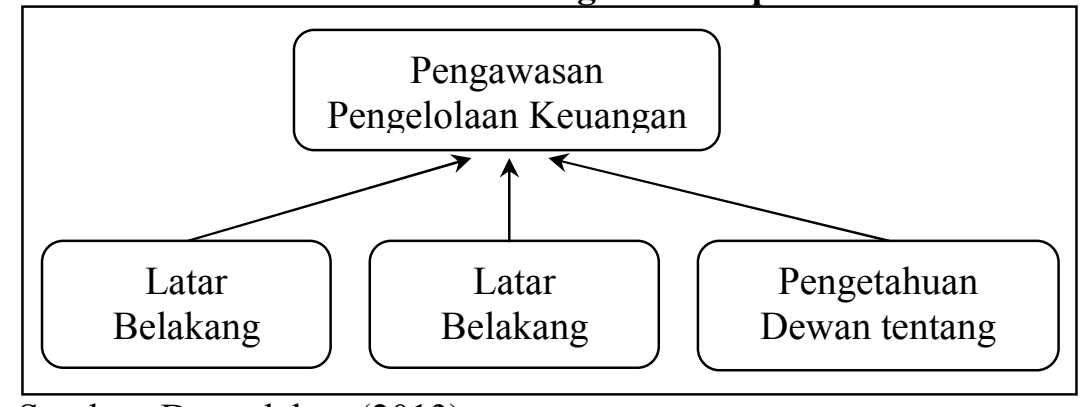

Sumber: Data olahan (2013)

\subsection{Proposisi}

\section{Latar Belakang Pribadi Menunjang Peran DPRD Dalam Pengawasan Keuangan Daerah}

Latar Belakang Pribadi menyangkut banyak aspek antara lain seperti nama, jenis kelamin, usia, agama, latar belakang pendidikan dan lain sebagainya. Individu yang berkualitas adalah individu yang memiliki pengetahuan, salah satunya pengetahuan akan pentingnya pengendalian dalam pembuatan anggaran dari dalam diri pembuat anggaran itu sendiri. Sumber daya manusia merupakan pilar penyangga utama sekaligus penggerak roda organisasi dalam usaha mewujudkan elemen organisasi yang sangat penting. Maka individu dalam peran sebagai DPRD harus memiliki pengetahuan yang 
cukup untuk mampu mengalokasikan sumber daya secara optimal, dengan demikian dapat memperkecil anggaran daerah.

\section{Latar Belakang Politik Menunjang Peran DPRD Dalam Pengawasan Keuangan Daerah}

Latar Belakang Politik merupakan latar belakang dari pengalaman seseorang dalam berkecimpung di dunia politik. Seorang anggota dewan harus mempunyai latar belakang politik yang baik dalam menjalankan tugasnya sebagai anggota dewan agar dapat memainkan peranannya dengan baik apabila pimpinan dan anggota-anggotanya berada dalam kualifikasi ideal dalam arti memahami benar hak, tugas dan wewenangnya dan mampu mengaplikasikannya secara baik, dan didukung dengan tingkat pendidikan dan pengalaman di bidang politik dan pemerintahan yang baik.

\section{Pengetahuan Dewan tentang Anggaran Menunjang Peran DPRD dalam Pengawasan Keuangan Daerah.}

Pengetahuan dewan tentang anggaran dapat diartikan sebagai pengetahuan dewan terhadap mekanisme penyusunan anggaran mulai dari tahap perencanaan sampai pada tahap pertanggungjawaban serta pengetahuan dewan tentang peraturan perundangan yang mengatur pengelolaan keuangan daerah/APBD. Pengalaman dan pengetahuan yang tinggi akan sangat membantu seseorang dalam memecahkan persoalan yang dihadapinya sesuai dengan kedudukan anggota DPRD sebagai wakil rakyat. Dalam menjalankan fungsi dan peran anggota dewan, kapasitas, dan profesi dewan sangat ditentukan oleh kemampuan bargaining position dalam memproduk suatu kebijakan anggota Dewan diharapkan dapat mendeteksi adanya pemborosan dan kebocoran anggaran.

\section{METODE PENELITIAN}

4.3 Jenis dan Sumber Data

Berdasarkan sumber pengambilannya, data dibedakan atas dua, yaitu data primer dan data sekunder (Hasan, 2008:19).

1. Data Primer; biasanya diperoleh dengan survei lapangan yang menggunakan semua metode pengumpulan data original (Kuncoro, 2003:127). Dalam penelitian ini, data primer berupa pertanyaan peneliti dan jawaban responden melalui kuesioner yang akan dibagikan kepada responden.

2. Data Sekunder; biasanya telah dikumpulkan oleh lembaga pengumpul data dan dipublikasikan kepada masyarakat pengguna data (Kuncoro, 2003:127). Dalam penelitian ini penulis mengambil data yang terkait relevan dengan masalah yang diangkat sebagai bahan dan materi dalam pembahasan dalam proposal tesis ini.

Data yang digunakan dalam penelitian ini adalah data primer yaitu data yang diperoleh melalui pengukuran langsung yang bukan berasal dari data yang telah ada.

Peneliti telah mengambil data langsung dari responden dengan menggunakan metode wawancara langsung (direct interview) berdasarkan daftar pertanyaan yang dibagikan kepada Anggota Dewan Perwakilan Rakyat Daerah (DPRD) Kabupaten Puncak Jaya.

\subsection{Teknik Pengumpulan Data}

Dalam usaha untuk memperoleh data dan informasi yang berkenaan dengan penelitian ini, serta sebagai bahan dan materi untuk keperluan dan pembahasan maka metode pengumpulan data yang diperoleh meliputi:

1. Survei Pendahuluan; langkah awal untuk mencari judul penelitian tesis dan masalah yang bisa diangkat menjadi bahan penelitian membaca Simposium Nasional Akuntansi (SNA), Jurnal Riset Akuntansi Indonesia (JRAI), maupun karya tulis ilmiah lainnya.

2. Survei Lapangan; penelitian langsung yang dilakukan pada DPRD Kabupaten Puncak Jaya dimana sebagian besar data diperoleh dengan teknik pengumpulan data berikut ini.

a. Pengamatan, yaitu teknik pengumpulan data yang dilakukan dengan cara langsung ke objek yang diteliti dan mengamati apa yang menjadi sasaran dalam pengambilan data. 
b. Daftar Pertanyaan atau Kuesioner, yaitu teknik pengumpulan data dengan cara membuat daftar pertanyaan yang berkaitan dengan pokok permasalahan dan membagikan kuesioner tersebut untuk diisi oleh dewan.

Pada penelitian ini, teknik wawancara yang digunakan adalah wawancara secara personal (personally direct interview). Wawancara ini terdiri dari tiga bagian, yaitu surat permohonan wawancara, data responden, dan daftar pertanyaan. Dalam hal ini Dewan Perwakilan Rakyat Daerah Kabupaten Puncak Jaya merupakan lokasi penelitian atau yang merupakan objek penelitian yang dilakukan oleh penulis.

\subsection{Obyek dan Waktu Penelitian}

Obyek dalam penelitian ini mengambil lokasi di Dewan Perwakilan Rakyat Daerah (DPRD) Kabupaten Puncak Jaya dengan waktu penelitian selama enam bulan, yaitu mulai bulan Oktober 2012 sampai dengan bulan Maret 2013.

\subsection{Populasi dan Sampel}

Populasi dalam penelitian ini adalah seluruh anggota DPRD pada Dewan Perwakilan Rakyat Daerah (DPRD) Kabupaten Puncak Jaya periode tahun 2009-2014 yang berjumlah 24 orang. Pengambilan sampel dilakukan dengan menggunakan metode Simple Random Sampling, dimana seluruh populasi menjadi sampel penelitian. Penelitian ini menggunakan metode pengumpulan data sensus yaitu penelitian yang dilakukan terhadap seluruh populasi.

\subsection{Metode dan Teknik Analisis}

Berdasarkan pada jenis dan sumber data serta teknik pengumpulan data maka, penelitian ini menggunakan metode analisis deskriptif kualitatif dengan teknik analisis perbandingan antara indikator yang telah ditentukan dengan jawaban yang diberikan berdasarkan kondisi aktual di lapangan.

\section{ANALISIS DAN PEMBAHASAN HASIL PENELITIAN}

\subsection{Latar Belakang Pribadi Anggota DPRD Kabupaten Puncak Jaya}

Dalam menilai latar belakang pribadi Anggota DPRD Kabupaten Puncak Jaya digunakan indikator:tingkat pendidikan, bidang pendidikan, pekerjaan sebelum menjadi anggota dewan, dan preferensi metode dalam proses pengambilan keputusan.

Tabel 5.1 Latar Belakang Tingkat Pendidikan

\begin{tabular}{|c|l|rl|rr|r|}
\hline No. & \multicolumn{1}{|c|}{ Uraian } & \multicolumn{2}{|c|}{ Jumlah } & \multicolumn{2}{|c|}{ Persentase } & Keterangan \\
\hline 1 & Magister (S2) & 2 & orang & 8,33 & $\%$ & \\
\hline 2 & Sarjana (S1) & 16 & orang & 66,66 & $\%$ & \\
\hline 3 & Diploma (DIII) & 1 & orang & 4,17 & $\%$ & \\
\hline 4 & SMA/sederajat & 5 & orang & 20,84 & $\%$ & \\
\hline & Jumlah & 24 & orang & 100,00 & $\%$ & \\
\hline
\end{tabular}

Sumber data: Hasil olahan (2013)

Berdasarkan rincian yang telah dijabarkan dalam Tabel 5.1, maka dapat dikatakan bahwa sebagian besar anggota Dewan memiliki kualifikasi pendidikan tinggi, yaitu 16 orang sarjana, 1 orang Ahli Madya (Diploma III) dan 2 orang lulusan pascasarjana. Kenyataan ini menunjukkan hal yang positif sebab anggota Dewan yang berpendidikan sarjana memiliki ide dan solusi serta sikap yang lebih responsif terhadap suatu permasalahan dibandingkan dengan yang berpendidikan dibawahnya.

Tabel 5.2 Latar Belakang Pekerjaan Sebelum Menjadi Anggota DPRD

\begin{tabular}{|c|l|rl|rr|r|}
\hline No. & \multicolumn{1}{|c|}{ Uraian } & \multicolumn{2}{|c|}{ Jumlah } & \multicolumn{2}{|c|}{ Persentase } & Keterangan \\
\hline 1 & Wiraswasta & 22 & Orang & 91,67 & $\%$ & \\
\hline 2 & Pegawai Negeri & 2 & Orang & 8,33 & $\%$ & \\
\hline & Jumlah & 24 & Orang & 100,00 & $\%$ & \\
\hline
\end{tabular}

Sumber data: Hasil olahan (2013) 
Anggota Dewan merupakan status politik yang memiliki prestise dan previlese tersendiri.Status politik tersebut menguat apabila anggota DPRD juga telah memiliki status sosial di tengah masyarakat.Para anggota DPRD Kabupaten Puncak Jaya sebelum mengemban amanah sebagai wakil rakyat telah memiliki pekerjaan yang dapat menunjang kehidupannya sehari-hari beserta keluarga. Berdasarkan tabel 5.4, sebagian besar anggota DPRD Kabupaten Puncak Jaya, yaitu 22 orang berlatar belakang sebagai wiraswasta, sedangkan 2 orang sebelumnya bekerja sebagai Pegawai Negeri (PNS/Anggota TNI/POLRI).

Tabel 5.3 Latar Belakang Preferensi Pengambilan Keputusan

\begin{tabular}{|c|l|rr|rr|r|}
\hline No. & \multicolumn{2}{|c|}{ Uraian } & \multicolumn{2}{|c|}{ Jumlah } & \multicolumn{3}{|c|}{ Persentase } & Keterangan \\
\hline 1 & Musyawarah & 19 & Orang & 79,12 & $\%$ & \\
\hline 2 & Pemungutan Suara (voting) & 5 & Orang & 20,88 & $\%$ & \\
\hline & Jumlah & 24 & Orang & 100,00 & $\%$ & \\
\hline
\end{tabular}

Sumber data: Hasil olahan (2013)

Selain faktor pendidikan dan pekerjaan, latar belakang pribadi yang turut mempengaruhi fungsi pengawasan atas pengelolaan keuangan daerah pada Anggota DPRD Kabupaten Puncak Jaya adalah preferensi dalam mengambil keputusan. Sebagian besar Anggota Dewan cenderung memilih sistem musyawarah dalam proses pengambilan keputusan yang terkait dengan fungsi pengawasan atas pengelolaan keuangan daerah Kabupaten Puncak Jaya. Hal ini dibuktikan dengan hasil penelitian pada tabel 5.1 dimana 19 orang Anggota DPRD Kabupaten Puncak Jaya memilih sistem musyawarah sedangkan sisanya (5 orang) memilih sistem pemungutan suara (voting).

\subsection{Latar Belakang Politik Anggota DPRD Kabupaten Puncak Jaya}

Latar belakang politik anggota DPRD Kabupaten Puncak Jaya dapat ditinjau dari asal partai politik, jabatan di partai politik, lama keanggotaan, dan pengalaman menjadi anggota DPRD.

Tabel 5.4 Asal Partai Politik

\begin{tabular}{|c|l|rr|rr|r|}
\hline No. & Uraian & \multicolumn{2}{|c|}{ Jumlah } & \multicolumn{2}{|c|}{ Persentase } & Keterangan \\
\hline 1 & Koalisi & 19 & orang & 79,16 & $\%$ & \\
\hline 2 & Oposisi & 5 & orang & 20,84 & $\%$ & \\
\hline & Jumlah & 24 & orang & 100,00 & $\%$ & \\
\hline
\end{tabular}

Sumber data: Hasil olahan (2013)

Berdasarkan fakta yang telah dijabarkan dalam Tabel 5.4, maka dapat dinyatakan bahwa sebagian besar Anggota DPRD Kabupaten Puncak Jaya (19 orang) adalah anggota dari kelompok koalisi dengan partai pemenang Pemiluhan Umum Kepala Daerah (Pemilukada) yaitu partai yang mengusung pasangan calon Bupati dan Wakil Bupati Puncak Jaya terpilih.Untuk mengimbangi kekuatan tersebut, maka lima orang Anggota Dewan memilih sikap beroposisi terhadap pihak petahana (incumbent).

Tabel 5.5 Latar Belakang Jabatan di Partai Politik

\begin{tabular}{|c|c|c|c|c|}
\hline No. & Uraian & Jumlah & Persentase & Keterangan \\
\hline 1 & Ketua & 2 orang & $8,33 \%$ & \\
\hline 2 & Sekretaris & 1 orang & $4,17 \%$ & \\
\hline 3 & Bendahara & 4 orang & $16,67 \%$ & \\
\hline 4 & Pengurus Biasa & 17 orang & $70,83 \%$ & \\
\hline & Jumlah & 24 orang & $100,00 \%$ & \\
\hline
\end{tabular}

Sumber data: Hasil olahan (2013)

Dari 24 orang Anggota DPRD Kabupaten Puncak Jaya, sebanyak 2 orang sedang memegang tampuk kepemimpinan pada partai politik asal masing-masing, 1 orang memangku jabatan sekretaris parpol, 4 orang bendahara, dan sisanya sebanyak 17 orang berkedudukan sebagai pengurus pada masing-masing parpol asal. 
Tabel 5.6 Latar Belakang Lama Keanggotaan Partai Politik

\begin{tabular}{|c|l|rr|rr|r|}
\hline No. & \multicolumn{1}{|c|}{ Uraian } & \multicolumn{1}{|c|}{ Jumlah } & \multicolumn{2}{|c|}{ Persentase } & Keterangan \\
\hline 1 & $>5$ tahun & 14 & orang & 58,33 & $\%$ & \\
\hline 2 & $1-5$ tahun & 8 & orang & 33,34 & $\%$ & \\
\hline 3 & $<1$ tahun & 2 & orang & 8,33 & $\%$ & \\
\hline & Jumlah & 24 & orang & 100,00 & $\%$ & \\
\hline
\end{tabular}

Sumber data: Hasil olahan (2013)

Berdasarkan tingkat senioritas berkiprah dalam partai politik sebagaimana terlihat dalam Tabel 5.8, Anggota DPRD Kabupaten Puncak Jaya didominasi oleh kader partai politik senior dalam artian bahwa 14 orang Anggota Dewan telah berkiprah selama lebih dari lima tahun dalam partai politik masing-masing. Kemudian 8 orang telah berkiprah antara 1 tahun sampai dengan 5 tahun sebagai anggota partai politik yang bersangkutan. Hanya dua orang Anggota DPRD Kabupaten Puncak Jaya yang masih minim pengalaman politik karena berkiprah kurang dari satu tahun.

Tabel 5.7 Latar Belakang Pengalaman Menjadi Anggota DPRD

\begin{tabular}{|c|l|rr|rr|r|}
\hline No. & \multicolumn{1}{|c|}{ Uraian } & \multicolumn{2}{|c|}{ Jumlah } & \multicolumn{2}{|c|}{ Persentase } & Keterangan \\
\hline 1 & pertama kali & 20 & orang & 83,33 & $\%$ & \\
\hline 2 & $>1$ periode & 4 & orang & 16,67 & $\%$ & \\
\hline & Jumlah & 24 & orang & 100,00 & $\%$ & \\
\hline
\end{tabular}

Sumber data: Hasil olahan (2013)

Berkaitan dengan itu, 20 orang Anggota DPRD Kabupaten Puncak Jaya masih dalam tahapan pemula,artinya mereka baru pertama kali terpilih menjadi Anggota Dewan. Sedangkan masa jabatan empat orang lainnya adalah kelanjutan dari periode sebelumnya, yaitu periode 2004-2009.

\subsection{Pengetahuan Anggota DPRD tentang APBD Kabupaten Puncak Jaya}

Indikator dalam menilai faktor pengetahuan anggota Dewan tentang APBD Kabupaten Puncak Jaya berupa pemahaman aturan tentang siklus pengelolaan keuangan daerah yaitu tahap penyusunan, penatausahaan, dan pertanggungjawab-an APBD, pemahaman regulasi yang mengatur tentang fungsi pengawasan keuangan oleh DPRD, serta pemahaman atas tugas pokok dan fungsi (tupoksi) dan struktur organisasi DPRD.

Tabel 5.8 Pemahaman Aturan Siklus Pengelolaan Keuangan Daerah

\begin{tabular}{|c|c|c|c|c|}
\hline No. & Uraian & Jumlah & Persentase & Keterangan \\
\hline 1 & Komprehensif (seluruh tahapan) & 8 orang & $33,33 \%$ & \\
\hline 2 & Parsial (hanya sebagian tahapan) & orang & 66,67 & \\
\hline & Jumlah & orang & 100,00 & \\
\hline
\end{tabular}

Sumber data: Hasil olahan (2013)

Rincian indikator pemahaman Anggota DPRD atas APBD Kabupaten Puncak Jaya dalam Tabel 5.3, menunjukkan bahwa hanya sebagian kecil (8 orang atau 33,33\%) Anggota DPRD Kabupaten Puncak Jaya yang menguasai pemahaman atas seluruh siklus pengelolaan keuangan daerah, yaitu sejak tahap perencanaan, kemudian ditindaklanjuti dengan tahap penatausahaan atau pelaksanaan APBD, lalu dilanjutkan dengan tahap pertanggungjawaban APBD Kabupaten Puncak Jaya pada tahun yang bersangkutan. Sedangkan mayoritas Anggota DPRD (66,67\% atau 16 orang) tidak memiliki pemahaman yang menyeluruh atas siklus pengelolaan keuangan daerah.

Tabel 5.9 Pemahaman Regulasi tentang Fungsi Pengawasan Keuangan

\begin{tabular}{|c|l|rr|rr|r|}
\hline No. & \multicolumn{1}{|c|}{ Uraian } & \multicolumn{2}{|c|}{ Jumlah } & \multicolumn{2}{|c|}{ Persentase } & Keterangan \\
\hline 1 & Paham & 3 & orang & 12,5 & $\%$ & \\
\hline 2 & Kurang paham & 21 & orang & 87,5 & $\%$ & \\
\hline & Jumlah & 24 & orang & 100,00 & $\%$ & \\
\hline
\end{tabular}

Sumber data: Hasil olahan (2013) 
Guna memperlancar pelaksanaan fungsi pengawasan pengelolaan keuangan daerah Kabupaten Puncak Jaya, maka para Anggota Dewan sebaiknya memiliki tingkat pemahaman yang tinggi terhadap regulasi-regulasi yang mengatur tentang pengawasan pengelolaan keuangan daerah. Hasil penelitian sebagaimana terlihat dalam Tabel 5.9 menunjukkan bahwa sebagian besar Anggota Dewan (21 orang) masih belum menguasai peraturan yang terkait dengan pengawasan pengelolaan keuangan daerah. Akibatnya, fungsi pengawasan pengelolaan keuangan daerah cenderung bertumpu kepada empat orang Anggota DPRD Kabupaten Puncak Jaya Periode 2009-2014 yang memiliki pemahaman paripurna atas peraturan berkaitan dengan fungsi pengawasan pengelolaan keuangan daerah.

Tabel 5.10 Pemahaman Tugas Pokok dan Fungsi (TUPOKSI) Struktur Organisasi

\begin{tabular}{|c|l|rr|rr|r|}
\hline No. & Uraian & \multicolumn{2}{|c|}{ Jumlah } & \multicolumn{2}{|c|}{ Persentase } & Keterangan \\
\hline 1 & Paham & 24 & orang & 100,00 & $\%$ & \\
\hline 2 & Kurang paham & 0 & orang & 0 & $\%$ & \\
\hline & Jumlah & 24 & orang & 100,00 & $\%$ & \\
\hline
\end{tabular}

Sumber data: Hasil olahan (2013)

Meskipun demikian, semua anggota DPRD Kabupaten Puncak Jaya telah mengetahui tugas pokok dan fungsi (tupoksi) serta struktur organisasi DPRD Kabupaten Puncak Jaya. Hal ini berimplikasi positif terhadap kelancaran pelaksanaan tugas DPRD sebagai representasi (perwakilan) rakyat di kabupaten Puncak Jaya.

\subsection{Pembahasan}

Wasistiono dan Wiyoso (2009) sebagaimana dikutip oleh Muhi (2011) mengungkapkan bahwa kedudukan DPRD dalam sistem pemerintahan daerah mengalami perubahan yang sangat dinamis. Pada saat sistem pemerintahan sangat desentralistik, maka kedudukan DPRD dibuat lemah. Sebaliknya, jika sistem pemerintahan sangat desentralistik, maka kedudukan DPRD dibuat sangat kuat.

Pada Undang-undang Nomor 32 Tahun 2004 tentang Pemerintahan Daerah secara tegas dinyatakan bahwa DPRD memiliki fungsi legislasi, anggaran dan pengawasan. Fungsi pengawasan merupakan salah satu fungsi terpenting DPRD dalam penyelenggaraan pemerintahan daerah. Pengawasan merupakan salah satu fungsi utama yang melekat pada Dewan Perwakilan Rakyat (DPRD) selain fungsi legislasi dan anggaran. Seyogyanya aspirasi masyarakat dalam bidang pengawasan, secara melembaga sudah terwakili melalui wakil-wakilnya yang duduk di DPRD. Fungsi pengawasan ini diharapkan bisa berjalan efektif sesuai harapan masyarakat, peraturan dan perundangundangan yang berlaku.

Pengawasan DPRD bertujuan untuk menjamin agar pemerintah daerah menjalankan programnya sesuai dengan rencana dan ketentuan perundangan yang berlaku. Fungsi pengawasan yang dilakukan oleh DPRD kepada eksekutif substansinya adalah mengarah pada pengawasan politik atau kebijakan. Namun demikian, fungsi pengawasan yang dijalankan oleh DPRD dinilai sebagian masyarakat belum optimal. Masyarakat mengkritik bahwa anggota DPRD dinilai tidak professional karena belum/tidak mampu mengoptimalkan fungsi pengawasan, sehingga penyerapan anggaran oleh eksekutif berjalan nyaris tanpa pengawasan yang berarti.Akibatnya, pembangunan yang seharusnya bermanfaat untuk rakyat, cenderung dilaksanakan secara "asal-asalan" oleh pemerintah daerah. Berbagai fenomena di atas menunjukkan bahwa anggota DPRD saat ini belum memberikan konstribusi maksimal bahkan kredibilitas dan eksistensinya semakin diragukan oleh rakyat.

\subsubsection{Pengaruh Latar Belakang Pribadi terhadap Fungsi Pengawasan Pengelolaan Keuangan Daerah Kabupaten Puncak Jaya}

Seseorang menjadi anggota DPRD merupakan pilihan rakyat, bukan seleksi seperti yang dilakukan oleh pemerintah (seleksi CPNS) maupun rekrutmen karyawan oleh perusahaan. Dengan demikian, tingkat pendidikan bukan dijadikan dasar seseorang dipilih menjadi anggota DPRD. Oleh karena itu, tingkat pendidikan akan kurang berpengaruh dalam pengawasan pengelolaan keuangan daerah yang baik. Hal ini dikarenakan tidak adanya tingkatan jabatan berdasarkan klasifikasi 
pendidikan pada lembaga DPRD, seperti layaknya pada jajaran pemerintah daerah (pihak eksekutif) dan perusahaan. Dengan kata lain, seluruh anggota DPRD memiliki tugas dan wewenang yang sama dalam melakukan pengawasan walaupun tingkat pendidikan yang dimiliki berbeda.

Relevansi bidang pendidikan juga akan kurang berpengaruh terhadap fungsi pengawasan pengelolaan keuangan daerah oleh Anggota DPRD Kabupaten Puncak Jaya. Hal ini disebabkan oleh beberapa responden tidak berasal dari bidang pendidikan yang relevan dengan bidang pengawasan dan keuangan seperti hukum, ekonomi, administrasi pemerintahan,dan sebagainya. Hal ini menyebabkan peran yang dijalankan oleh DPRD Kabupaten Puncak Jaya dalam melakukan pengawasan pengelolaan keuangan daerah menjadi tidak maksimal. Selain itu penempatan seorang anggota dewan ke dalam komisi yang membidangi pengawasan pengelolaan keuangan daerah biasanya berdasarkan rekomendasi fraksi anggota dewan yang ada di DPRD, bukan melihat bidang pendidikan yang dimiliki.

Latar belakang pekerjaan juga akan kurang berpengaruh dalam fungsi pengawasan pengelolaan keuangan daerah oleh Anggota DPRD Kabupaten Puncak Jaya. Hal ini disebabkan oleh sebagian besar anggota DPRD tidak memiliki latar belakang pekerjaan yang berhubungan dengan fungsi pengawasan. Selain itu, latar belakang pekerjaan turut berpengaruh terhadap motif-motif ekonomi untuk mendapatkan finansial lebih banyak melalui program kerja keluar daerah seperti bimbingan teknis (bimtek), kunjungan kerja, dan studi banding.

\subsubsection{Pengaruh Latar Belakang Politik terhadap Fungsi Pengawasan Pengelolaan Keuangan} Daerah Kabupaten Puncak Jaya

Asal parpol (koalisi atau oposisi) berpengaruh terhadap fungsi pengawasan pengelolaan keuangan daerah. Anggota DPRD yang berasal dari partai koalisi memiliki peran yang lebih besar dalam pengawasan keuangan daerah dibanding partai oposisi.Pada lembaga legislatif (DPRD) sering kali perumusan dan pengesahan kebijakan pemerintah dilakukan secara voting (pemungutan suara). Dalam kondisi seperti ini biasanya suara partai koalisi akan lebih dominan dibanding partai oposisi. Hal ini mengakibatkan anggota DPRD yang berasal dari partai koalisi akan memiliki peran pengawasan keuangan daerah yang lebih besar dibanding anggota DPRD yang berasal dari partai oposisi.

Pengalaman di DPRD berpengaruh terhadap fungsi pengawasan pengelolaan keuangan daerah pada anggota DPRD Kabupaten Puncak Jaya. Semakin lama seseorang menjadi anggota DPRD, maka semakin besar pula pengalaman dan pengetahuan yang dimiliki dalam mengawasi pengelolaan keuangan daerah.

\subsubsection{Pengaruh Pengetahuan Dewan tentang APBD terhadap Fungsi Pengawasan Pengelolaan Keuangan Daerah Kabupaten Puncak Jaya}

Pemahaman regulasi tentang pengelolaan keuangan daerah berpengaruh terhadap fungsi pengawasan pengelolaan keuangan daerah oleh anggota DPRD Kabupaten Puncak Jaya. Anggota DPRD yang memiliki pemahaman regulasi yang baik mengenai keuangan daerah akan mudah mengawasi apakah APBD telah berjalan sesuai dengan tujuan yang telah ditetapkan sebelumnya dan mendeteksi terjadinya kebocoran anggaran. Hal ini dikarenakan regulasi tentang pengelolaan keuangan daerah ditujukan untuk membantu anggota dewan dalam memastikan apakah pengelolaan keuangan daerah telah sesuai dengan tujuan dan peraturan perundang-undangan yang ditetapkan.

\section{SIMPULAN DAN SARAN}

\subsection{Simpulan}

Berdasarkan rumusan masalah, tujuan penelitian, hasil penelitian dan pembahasan yang telah diuraikan sebelumnya, maka dapat ditarik beberapa simpulan berikut ini.

1. Latar belakang pribadi Anggota DPRD Kabupaten Puncak Jaya akan kurang berpengaruh terhadap fungsi pengawasan pengelolaan keuangan daerah yang baik. Tingkat pendidikan akan kurang berpengaruh terhadap fungsi pengawasan yang baik karena tidak adanya tingkatan 
jabatan berdasarkan klasifikasi pendidikan pada lembaga DPRD, seperti layaknya pada jajaran pemerintah daerah (pihak eksekutif) dan perusahaan. Selain itu, penempatan seorang anggota dewan ke dalam komisi yang membidangi pengawasan pengelolaan keuangan daerah biasanya berdasarkan rekomendasi fraksi anggota dewan yang ada di DPRD, bukan melihat bidang pendidikan yang dimiliki. Sebagian besar anggota DPRD tidak memiliki latar belakang pekerjaan yang berhubungan dengan fungsi pengawasan.

2. Latar belakang politik anggota DPRD Kabupaten Puncak Jaya berpengaruh terhadap fungsi pengawasan pengelolaan keuangan daerah. Anggota DPRD yang berasal dari partai koalisi memiliki peran yang lebih besar dalam pengawasan keuangan daerah dibanding partai oposisi. Semakin lama seseorang menjadi anggota DPRD, maka semakin besar pula pengalaman dan pengetahuan yang dimiliki dalam mengawasi pengelolaan keuangan daerah.

3. Pengetahuan anggota Dewan tentang APBD Kabupaten Puncak Jaya berpengaruh dalam pengawasan pengelolaan keuangan daerah yang baik. Anggota DPRD yang memiliki pemahaman regulasi yang baik mengenai keuangan daerah akan mudah mengawasi apakah APBD telah berjalan sesuai dengan tujuan yang telah ditetapkan sebelumnya dan mendeteksi terjadinya kebocoran anggaran.

\subsection{Saran}

Berdasarkan perbandingan antara kondisi ideal berdasarkan teori dengan kenyataan yang terjadi di lapangan, maka disarankan hal-hal berikut ini.

1. Salah satu aspek yang harus diatur secara hati-hati oleh Pemerintah Daerah Kabupaten Puncak Jaya adalah pengelolaan keuangan daerah karena anggaran daerah memainkan peranan yang sangat penting dalam mendukung siklus penyelenggaraan pemerintah daerah untuk menciptakan kesejahteraan bagi masyarakatnya. Dalam menjalankan fungsi pengawasan, DPRD dianggap kurang maksimal. Terbukti dengan banyaknya ketimpangan-ketimpangan yang terjadi di berbagai daerah di Indonesia.

2. DPRD Kabupaten Puncak Jaya hendaknya rutin melaksanakan kegiatan pendidikan dan pelatihan (diklat) tentang pengawasan pengelolaan keuangan daerah bagi para anggota dewan secara terarah dan berkesinambungan sehingga mereka dapat memahami tugas dan fungsinya.

3. DPRD seyogyanya membuat pedoman pokok pengawasan pengelolaan keuangan daerah yang dapat menguatkan posisi DPRD dalam menjalankan tugas dan wewenangnya agar bisa berperan dalam fungsi pengawasan secara optimal.

\section{DAFTAR PUSTAKA}

Bastian, Indra. 2005. Akuntansi Sektor Publik: Suatu Pengantar. Jakarta: Erlangga.

Halim, Abdul dan Muhammad Syam Kusufi. 2012. Akuntansi Sektor Publik: Akuntansi Keuangan Daerah (SAP Berbasis Akrual) Edisi 4. Jakarta: Salemba Empat.

Hasan, Iqbal. 2008. Analisis Data Penelitian dengan Statistik. Jakarta: Bumi Aksara.

Kombaitan, Yanty. 2009. Pengaruh Pengetahuan Dewan Tentang Anggaran, Kapasitas Individu, Sistem Akuntansi Keuangan Daerah, dan Pengawasan Keuangan Daerah Terhadap Partisipasi Anggaran pada Dewan Perwakilan Rakyat Daerah Kabupaten Minahasa. Skripsi Tidak Dipublikasikan. Fakultas Ekonomi Unsrat Manado.

Kuncoro, Mudrajad. 2003. Metode Riset untuk Bisnis dan Ekonomi. Jakarta: Erlangga.

La Palombara, J. 2002. Politics with in Nation. Englewood Cliffs: Prentice-Hall Inc. 
Menteri Negara Otonomi Daerah dan Pusat Antar Universitas-Studi Ekonomi UGM. 2000. Modul Pembekalan Teknis Manajemen Stratejik dan Teknik Penganggaran/Keuangan Bagi Anggota DPRD dan Pejabat Pemerintahan Daerah.

Muhi, Ali Hanapiah. 2011. Optimalisasi Pelaksanaan Fungsi Pengawasan Dewan Perwakilan Rakyat Daerah dalam Penyelenggaraan Pemerintahan. Bahan Kuliah. Institut Pemerintahan Dalam Negeri (IPDN), Jatinangor.

Republik Indonesia. 2000. Peraturan Pemerintah Nomor 105 Tahun 2000 tentang Pengelolaan dan Pertanggungjawaban Keuangan Daerah (Lembaran Negara Republik Indonesia Tahun 2000 Nomor 202, Tambahan Lembaran Negara Republik Indonesia Nomor 4022).

Republik Indonesia. 2001. Keputusan Presiden Nomor 74 Tahun 2001 tentang Tata Cara Pengawasan Penyelengaraan Pemerintahan Daerah.

Republik Indonesia. 2005. Peraturan Pemerintah Republik Indonesia Nomor 58 Tahun 2005 tentang Pengelolaan Keuangan Daerah.

Republik Indonesia. 2006. Peraturan Menteri Dalam Negeri Nomor 13 Tahun 2006 tentang Pedoman Pengelolaan Keuangan Daerah.

Sari, Imelda. 2010. Pengaruh Personal Background dan Political Background serta Pengetahuan Dewan Tentang Anggaran Terhadap Kinerja DPRD dalam Pengawasan Keuangan Daerah/APBD. Tesis Tidak Dipublikasikan. Program Pascasarjana Magister Akuntansi Universitas Sumatera Utara Medan, Agustus 2010.

Werimon, Simson, Imam Ghozali, dan Mohamad Nazir. 2007. Pengaruh Partisipasi Masyarakat dan Transparansi Kebijakan Publik terhadap Hubungan antara Pengetahuan Dewan tentang Anggaran dengan Pengawasan Keuangan Daerah (APBD). Simposium Nasional Akuntansi 10, Unhas Makassar.

Winarna, Jaka dan Sri Murni. 2007. Pengaruh Personal Background, Political Background dan Pengetahuan Dewan tentang Anggaran terhadap Peran DPRD dalam Pengawasan Keuangan Daerah. Simposium Nasional Akuntansi 10, Unhas Makassar.

Yudono, Bambang. 2002. Optimalisasi Peran DPRD dalam Penyelenggaraan Pemerintah Daerah. http://www.bangda.depdagri.go.id/jurnal/jendela/jendela3.htm. 